$\mathrm{A}$ 群ロ夕ウイルスが関与した成牛下痢症

$$
\text { 小沼成尚 }{ }^{1 \dagger} \quad \text { 工藤一磨 }^{11} \quad \text { 小川秀治 }{ }^{1)} \quad \text { 桜田まみ }{ }^{11}
$$

砂原栄子 ${ }^{1)} \quad$ 馬渡隆寛 $^{2)}$ 恒光 裕 $^{3)}$

1）秋田県中央家畜保健衛生所（广 011-0904 秋田市寺内蛭根 1-15-5）

2）山形県中央家畜保健衛生所（广 990-2161 山形市漆山 736）

3）独立行政法人農業技術研究機構動物衛生研究所七戸研究施設（ 产 039-2586 上北郡七 戸町字海内 31)

(2002 年 11 月 5 日受付 $\cdot 2003$ 年 1 月 16 日受理)

要約

2001 年 1 月, 秋田県のホルスタイン種飼養 1 農場で成牛 3 頭に下痢が発生した. 下痢便 3 例を用いた寄生虫検查と細 菌検查では下㾥起因病原体は検出されなかった。いっぽう, 電子顕微鏡観察によりロタウイルス様粒子のみが確認さ れ，下痢便から抽出したRNAの電気泳動によりA群ロタウイルス（GAR）特有の分節RNAが認められた．また，ウイ ルス分離により 2 例から GAR が分離され，分離株のVP7 血清型はG6, VP4 遺伝子型は $\mathrm{P}$ [1] であった. 分離株を用 いた発症牛 3 頭と同居牛 7 頭に扔ける血清中の中和抗体検查では, 発症牛 2 頭, 同居牛 1 頭に有意な抗体上昇が碓認さ れた. 以上の結果から, 本症例は今までほとんど報告のなかった牛 GAR 単独感染による成牛下㾥症と考えられた。 一キーワード: 成牛, 下痢, A 群ロタウイルス, 血清型, 中和抗体.

日獣会誌 56，245～248（2003）

ロタウイルス病はロタウイルスの感染に起因する急性 伝染病で, 下痢と脱水を主徵とする. 本ウイルスは多く の哺乳類と鳥類の粪便から検出され, 由来動物種ごとに 牛ロタウイルス, ヒトロタウイルスなどと呼ばれて区別 されているが, まれに動物種の壁を越えて感染すること も知られている $[16,26]$. ロタウイルスはVP6抗原の違 いにより $\mathrm{A} \sim \mathrm{F}$ 群の 6 群に大別され，牛ロタウイルスは $\mathrm{A}, \mathrm{B}$ および $\mathrm{C}$ 群の 3 群が報告されている $[12,18,23]$. A群ロタウイルス (GAR) 病は, ヒトにおいては3歳 までの子供に多く発生が見られる他, 大人の GAR 感染 に起因する下痢も報告されている $[1,11,13]$. いっぽ う，牛においては子牛での GAR 病について多くの報告 がなされているが, 成牛での本ウイルス感染の多くは不 顕性感染であると考えられており [17], 発症例の報告 はきわめて少ない $[20]$. 今回, ホルスタイン種飼養農 家で認められた成牛の下痢症について病性鑑定を実施し た結果, 牛 GAR 病が疑われたので, その概要を報告する.

\section{材料および方 法}

検査材料： 2001 年 1 月 22 日, 秋田県のホルスタイン
種成牛 35 頭, 育成牛 10 頭を飼養する 1 農場において, 4 歳 1 頭, 2 歳 2 頭, 計 3 頭の成牛に元気消失, 食欲不振 および激しい水様性の下痢がみられた。下痢は約 3 日間 持続し，下痢の発生はこれら 3 頭のみであった。発症牛 3 頭から下痢発症時に採取した下痢便と血清, 同時期に 同居成牛 7 頭から採取した血清，また，下痢発生から 21 日後にこれらの牛から採取した血清を検査材料とした。

寄生虫ならびに細菌検査：寄生虫検査は下痢便の直接 塗抹鏡検ならびにショ糖液浮遊法により虫体と虫卵を検 査した。細菌検査は, 下痢便を $5 \%$ 羊血液加寒天培地, DHL 寒天培地および卵黄加 CW 寒天培地で好気あるい は嫌気培養した. また, HTT培地と $20 \mathrm{mg} / \mathrm{ml}$ ノボビオ シン加DHL培地でサルモネラ検査を実施した。病原因 子検索は, 毒素原性大腸菌線毛 (K88 - K99 - 987P) 抗原検査 $^{\text {a) }}$ と, EAE [27], LT およびVT 遺伝子検查 ${ }^{\text {b), c) }}$

a) 毒素原性大腸菌線毛抗血清セット, デンカ生研(侏), 東京.

b）毒素源性大腸菌 LT 遺伝子検出用プライマーセット, タカラ バイオ(秼)，滋賀.

c）腸管出血性大腸菌 VT遺伝子検出用プライマーセット, タカ ラバイオ(株), 滋賀.

\footnotetext{
$\dagger$ 連絡責任者：小沼成尚（秋田県中央家畜保健衛生所）

干 011-0904 秋田市寺内蛭根 1-15-5

శా018-864-0401 FAX 018-862-7132

日獣会誌 $56 \quad 245 \sim 248$ (2003) 
を実施した。

ウイルス検出：下痢便中のウイルス検査として，ウイ ルス抗原検查, RT-PCR 法によるウイルス遺伝子検查, ウイルス分離，および電子顕微鏡法 $(\mathrm{EM})$ によるウイ ルス粒子の検索を実施した。

ウイルス抗原の検相は，市販のGAR抗原㛟出キット 扝よびアデノウイルス抗原検出キット”を使用した。

遺伝子検查：下痢便から TRIzol LS Reagent ${ }^{\mathrm{t}}$ で RNA を抽出し，牛コロナウイルス (BCV) S1 遺伝子の) 1146 塩基を標的として $[22]$, また牛ウイルス性下痢・粘膜 病（BVD-MD）ウイルス 5’非翻訳領域の286 塩基を標 的として [25], RT-PCR法で行った。

ウイルス分離：下㾥便をリン酸緩衝生理食塭液 (PBS) で10\%乳剤にして低速遠心後，その上清を接種材料と した。なお，ロタウイルスの分離には接種材料に $10 \mu \mathrm{g} /$ $\mathrm{m} l$ のトリプシン を添加し, $37^{\circ} \mathrm{C} 30$ 分感作させたもの を用いた。分離用細胞として，牛胎子筋肉 (BFM) 細 胞，牛腎由来株化 (MDBK) 細胞，抢よび牛精巣 (BT) 細胞を $37{ }^{\circ} \mathrm{C}$ で静置培養した。また，ヒ卜直腸由来株化 （HRT-18）細胞とアカゲザル腎由来株化（MA104）絒 胞には維持液にそれぞれ $0.1 \mu \mathrm{g} / \mathrm{m} l, 1 \mu \mathrm{g} / \mathrm{m} l$ のトリフ シンを添加して $37^{\circ} \mathrm{C} て ゙$ 回転培養した。分離の有無の確 認は紼胞変性効果（CPE）を指標として行い，CPEが 認められない場合は 1 造間間隔で2回継代した。GARの 同定は一次抗体に抗牛 GAR 免疫鬼血清 ${ }^{n}$, 二 二次抗体に FITC 標識抗忽 $\operatorname{IgG}$ を用いた間接蛍光抗体法 (IFA) で 行った。

EM：翼便乳剂を支持膜に滴下後，2\%リンタングス テン峻でネガティブ染色して電子顕微鏡で観察した。

ウイルス抗体検査：発症牛と同居牛のペア血清を用い てマイクロタイター法により中和試験を実施した。使用 ウイルスは, BCV Kakegawa株，牛アデノウイルス 3 型 WBR-1 株，牛アデノウイルス 7 型袋井株，BVDMDウイルスNOSE株, および本研究で分離した牛 GAR 分離株 RONO-1 株で，それぞれ HRT-18 細胞, MDBK 細胞，BT細胞，BFM 細胞，およびMA104 細 胞を使用した。なお， ロタウイルスの中和試験は維持液 に $1 \mu \mathrm{g} / \mathrm{m} l$ トリプシンを加えて実施した。

RNAのポリアクリルアミドゲル電気泳動：糞便から 抽出したRNAを10\%ポリアクリルアミドゲルで電気泳 動後，市販キット’で銀染色した。

d）イムノカードSTロタウイルス，蛛TFB，東京.

e）ディップスティック栄研アデノ，栄研化学株，東京.

f）インビトロジェン侏，東京。

g) Trypsin Type I, (㧣シグマ，アルドリッチ・ジヤパン(陎), 東京.

h）動物用生物学的製剂協会, 東京. i) コスモバイオ(侏, 東京. j）シルバーステインプラス，日本バイオラッド・ラボラトリー (株)，東京.
GAR のVP7 血清型別ならびにVP4 遺伝子型別： GAR 分離怢 2 怢から RNAを抽出し, RT-PCR 法により VP7 遺伝子 (1062bp) [9] とVP4 遺伝子の5’末端から $880 b p$ [8］音増させた。増幅産物を鋳型としてダイ レクトシーケンシングにより塭基配列を決定した。決定 された配列と既知の両遺伝子との相似性検索をインター ネット上で (http://www.ncbi.nlm.nih.gov/blast/) BLASTプログラムにより実施し，相似性の最も高い株 のVP7 血清型あるいはVP4 遺伝子型を分離株のそれら と判断した。なお，分離株と相似性の最も高い株との一 致率はClustral Wプログラムにより算出した。

\section{成績}

寄生虫ならびに細菌検査：粪便材料 3 例のいずれから も下痢関連の寄生虫ならびに細菌は検出されなからた。 また，各材料から分離された大腸菌数は $10^{4} \mathrm{CFU} / \mathrm{m} l$ 以 下であった。

ウイルス検出：EMによりロタウイルス様粒子がいず れの糞便材料からも検出されたのに対し，他のウイルス 様粒子は認められなかった。ウイルス抗原検出キットで は3例の粪便材料すべてGAR 陽性を示したが，アデノ ウイルスはいずれも㓌性であった。また，BCVならび にBVD-MD ウイルス遺伝子検出用 RT-PCR法ではい ずれの材料も㓌性であった。

ウイルス分離では，MA104細胞に接種した 3 例中 2 例で接種 1 代目からCPEがみられた。IFAにより分離 ウイルスは牛GAR と同定され，それら分離株は個体番 号 5 由来のものを RONO-1 株，また，個体番号 10 由来 のものをRONO-2株とそれぞれ命名された。いらぽう, 他の細胞ではCPEはまったくみられなかった。また，3 例の糞便から抽出したRNAの電気泳動によりGAR特有 の11本の分節 RNA (4-2-3-2) が確認され，それらは いずれも同一像を示した（四1)。

中和抗体検査：GAR 以外のウイルスに拈いては，抗

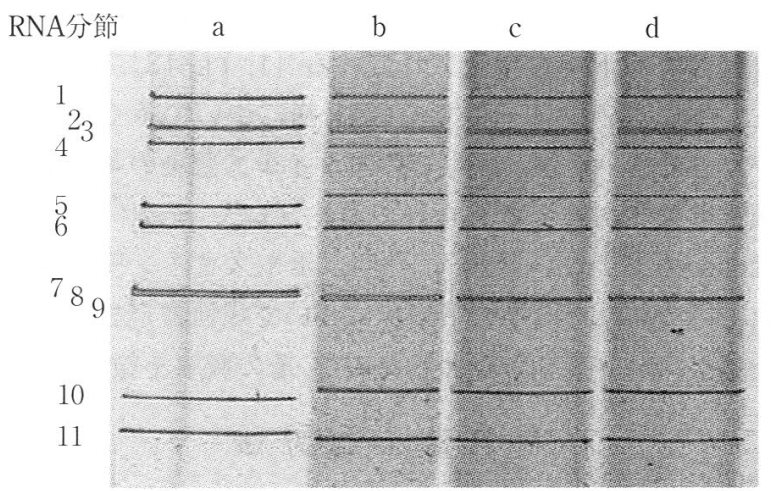

困1 RNA-ポリアクリルアミドゲル電気泳動像. 1 11 : 分節番号, a : 豚 A 群ロタウイルス OSU 株, $\mathrm{b}$ ：糞便 $1, \mathrm{c}$ ：糞便 $2, \mathrm{~d}$ ：萁便 3 . 
表 1 下痢発症牛ならびに同居牛における組血清を用い た中和試験および粪便のウイルス検査

\begin{tabular}{|c|c|c|c|c|c|c|}
\hline \multirow{2}{*}{$\begin{array}{l}\text { 個体 } \\
\text { 番号 }\end{array}$} & \multirow{2}{*}{$\begin{array}{l}\text { 年齢 } \\
\text { (歳) }\end{array}$} & \multirow{2}{*}{$\begin{array}{l}\text { 下痢発症 } \\
\text { の有無 }\end{array}$} & \multicolumn{2}{|c|}{ 抗 体 価 } & \multicolumn{2}{|c|}{ 糞便のロタウイルス検査 } \\
\hline & & & 急性期b) & 回復期 ${ }^{c)}$ & $\begin{array}{l}\text { RNA } \\
\text { 分節検出 }\end{array}$ & $\begin{array}{l}\text { ウイルス } \\
\text { 分離 }\end{array}$ \\
\hline 1 & 7 & 無 & 256 & 256 & 検査せず & 検査せず \\
\hline 2 & 7 & 無 & 32 & 32 & 検査せず & 検査せず \\
\hline 3 & 1 & 無 & 256 & 256 & 検査せず & 検査せず \\
\hline 4 & 2 & 有 & 64 & 128 & 陽 & 陰 \\
\hline 5 & 4 & 有 & 8 & 64 & 陽 & 陽 \\
\hline 6 & 2 & 無 & 8 & 16 & 検査せず & 検査せず \\
\hline 7 & 1 & 無 & 128 & 128 & 検査せず & 検査せず \\
\hline 8 & 1 & 無 & 32 & 128 & 検査せず & 検査せず \\
\hline 9 & 1 & 無 & 32 & 64 & 検査せず & 検査せず \\
\hline 10 & 2 & 有 & 64 & 256 & 陽性 & 陽性 \\
\hline
\end{tabular}

a）中和試験には個体番号 5 から分離したRONO-1株を用 いた

b) 発症時

c）初回採材から21日後

体価の有意上昇はみられなかった。いっぽう，GARに 対しては，発症牛 3 頭中 GARが分離された 2 頭と同居 牛 1 頭に有意な抗体価の上昇が認められた（表1）。

GAR のVP7 血清型とVP4 遺伝子型：分離株 2 株 VP7 遺伝子 951 塩基の配列を決定した結果，両者はまったく 同一であった。既報株との比較では，牛 GAR RF 株 （VP7 血清型 G6；GenBankアクセッション番号 X65940）と塩基配列で $99.8 \%$ と最も高い一致率を示し た.よって，検出株のVP7 血清型は $\mathrm{G} 6$ と判明した。分 離株 2 株 VP4 遺伝子 5 末 端より 780 塩基の配列を決定し た結果，両者はまったく同一であった．既報株との比較 では，VP7 遺伝子と同様に牛 GAR RF 株（VP4 遺伝子 型P［1］；GenBankアクセッション番号U65924）と 塩基配列で $99.7 \%$ と最も高い一致率を示した。よって, 分離株のVP4 遺伝子型はP [1] であることが示された.

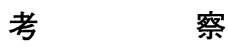

成牛にみられる集団下痢症の主要原因は BCVであり, 特に冬季での成牛下痢症の多くは BCVに起因するもの と考えられている $[3,21]$. しかし，時にBCVが関与し ない成牛のウイルス性下痢症も認められ，その原因とし て牛 B 群ロタウイルスや牛 C 群ロタウイルス，また BVD-MD ウイルス $[2,12,23]$ が報告されている。い っぽう, 牛 GAR は子牛下㾥症の主要原因であり [18], わが国においても子牛下痢便からの本ウイルスの検出例 が数多く報告されている $[10,15,19]$. しかし，牛 GAR が関与したとされる成牛下痢症に関してはほとんど報告 例はなかった。いっぽう，ヒトにおいては，GARによ る成人下痢症に関して幾つか報告され, 散発的な成人下 㾥症の $5 \sim 10 \%$ GARが関与していると考えられてい る [11]。今回，われわれは成牛下㾥症に遭遇し，下痢
関連病原体として牛 GARのみが検出された。また，発 症牛に㧍いて牛 GARに対する中和抗体価の有意上昇を 確認した.これらのことから, 本症例は過去にほとんど 報告のなかった牛 GAR 単独感染による成牛下痢症であ る可能性が強く示唆された。よって，今後は牛GARは 子牛だけでなく成牛下㾥症の原因因子として着目する必 要があると考えられた。なお, 疫学的関連調查では, 畜 主は人工授精師であるため, 他の農場への出入りはあっ たが, 同時期に近隣農場での下痢症の発生はみられなか った。また, 当該農場での牛の導入は 1999 年以降はな く, 感染経路は特定出来なかった.

牛 GARの主なVP7 血清型は G6, G8 お おび $\mathrm{G} 10$, VP4遺伝子型は $\mathrm{P}$ [1]，P［5］およびP [11］であると 報告されている [16]．今回検出された株のVP7 血清型 は G6，VP4 遺伝子型はP [1] であった. Falcone ら [5]は 149 例の子牛下㾥症から分離された牛 GARの VP7 血清型とVP4 遺伝子型の検出頻度は, G6P [5] (38.3\%), G10P [11] (31.5\%), G6P [11] (3.6\%) の順で多く認められたと報告している。日本では， Ishizaki ら［14］が子牛下㾥症由来 76 株について調べ た結果，G6P［5］(60.5\%), G10P [11] (17.1\%), G6P [11］(9.2\%)，G10P [5]（6.6\%）の組み合わせ が認められたが，G6P [1]はまったくみられなかった としている。また, Fukaiら $[6,7] は$ は, 子牛下淑症由 来 28 株のVP7 血清型とVP4 遺伝子型は G6P [5] (89.3\%), G6P [11] (7.1\%), G10P [11] (3.6\%) で あったこと，また，1995～1998年での鹿児島県内の子 牛下痢便 104 検体についての調查では，優位な VP7 血 清型と VP4 遺伝子型は年次により異なり, VP4 遺伝子 型は 1996 年の $\mathrm{P}$ [1] を含む混合型が優位であった以外 はP [5]，P［11］であったことを報告している．いっ ぽう，成牛由来株についてはSato ら［20］の報告があ るのみで, G8P [1] であったとしている.すなわち， 子牛由来の GARではVP4 遺伝子型がP [1] を示す株は 野外ではあまり優位でないのに対し，成牛由来では既報 ならびに今回の両者とも当該遺伝子型は $\mathrm{P}$ [1] であっ た。これらのことから，成牛下痢発現の要因として，P [1] を示す株に対する免疫状態が低かったこと，あるい は，P［1］を示す株の病原性が強いことが推測された。

牛 GARに対する血清中の中和抗体検查を実施した. 中和抗体はウイルス外殼蛋白のVP7 と VP4 の両者に対 する免疫応答として誘導されると考えられている [24]. 今回, 急性期の段階でいずれの材料も抗体価 8～256 倍 の範囲で中和抗体を保有しており，牛GARに対する高 い抗体保有率が示された。いっぽう，血清中抗体価と防 御との関連では，中和抗体価が 128 倍以上のものには発 症が見られなかった。しかし，64倍以下の抗体価を有 する牛では発症の有無はさまざまであり，必ずしも血清 
中抗体価が低いからといって感染や発症を起こすとは限 らなかった。ヒトでは血清中の中和抗体価よりも糞便中 の IgA 抗体価が発症防御の指標となると報告されている [4]. 今後はこの点について, 症例数を積み重ねて検討 していきたい.

\section{引用 文 献}

[1] Bishop RF:In A. Z. Kapikian (ed) : Viral infection of the gastrointestial tract, 131-167, Marce Dekker, Inc, New York, N.Y. (1994)

[2] Bolin SR, Mc Clurkin AW, Cutlip RC, Coria MF : Am J Vet Res, 46, 2467-2470 (1985)

[3 ] Clark MA : Br Vet J, 149, 51-70 (1993)

[4] Coulson BS, Grimwood K, Hudson I, Barnes GL and Bishop RF : J Clin Microbiol, 30, 1678-1684 (1992)

[5] Falcone E, Tarantino M, Di Trani L, Cordioli P, Lavazza A, Tollis M : J Clin microbiol, 37, 3879-3882 (1999)

[6] Fukai K, Maeda Y, Fujimoto K, Itou T, Sakai T : Vet Microbiol, 86, 343-349 (2002)

[ 7 ] Fukai K, Sakai T, Kamata H : Aust Vet J, 76, 418-422 (1998)

[8] Gentsch JR, Glass RI, Woods P, Gouvea V, Gorziglia M, Flores J, Das BK, Bhan MK : J Clin Microbiol, 30, 1365-1373 (1992)

[9] Gouvea V, Glass RI, Woods P, Taniguchi K, Clark KF, Forrester B, Fang ZY : J Clin Microbiol, 28, 276282 (1990)

[10] Goto Y, Kurogi H, Inaba Y, Matumoto M : Vet Microbiol, 11, 177-184 (1986)

[11] Griffin DD, Fletcher M, Levy ME, Ching-Lee M, Nogami R, Edwards L, Peters H, Montague L, Gentsch JR, Glass RI : J Infect Dis, 185, 1502-1505 (2002)

[12] Hayashi M, Nagai M, Hayakawa Y, Takeuchi K,
Tsunemitsu H : Vet Rec, 149, 331-332 (2001)

[13] Hrdy DB : Rev Infect. Dis. 9, 461-469 (1987)

[14] Ishizaki H, Sakai T, Shirahata T, Taniguchi K, Urasawa T, Urasawa S, Goto H : Vet Microbiol, 48, 367372 (1996)

［15］児玉 道, 小倉与四夫, 竹中寛睦, 山下秀之, 橋本和典, 伊東保一郎, 笹原二郎: 家畜衛生研究報告, 77, 1-8 (1978)

[16] Mebus CA, Wyatt RG, Sharpee RL, Sereno MM, Kalica AR, Kapikian AZ, Twienhaus MJ : Infect Immun, 14, 471-474 (1976)

［17］村上洋介：牛病学, 清水高正編, 第 2版, 238-240, 近 代出版, 東京 (1988)

[18] Saif LJ, Fernandez FM : J Infect Dis, 174, Suppl 1 S98-106 (1996)

[19] Sato K, Inaba Y, Takahasi E, Ito Y, Kurogi H, Akashi H, Satoda K, Omori T, Matumoto M : Microbiol Immunol, 22, 499-503 (1978)

[20] Sato M, Nakagomi T, Tajima K, Ezura K, Akashi H, Nakagomi O : J Clin Microbiol, 35, 1266-1268 (1997)

[21] Takahashi E, Akashi H, Inaba Y : JARQ, 17, 185-190 (1983)

[22] Tsunemitsu H, Smith DR, Saif LJ : Arch Virol, 144, 167-175 (1999)

[23] Tsunemitsu H, Saif LJ, Jiang B, Shimizu M, Hiro M, yamaguchi $\mathrm{H}$, Ishiyama T, Hirai $\mathrm{T}$ : J Clin Microbiol, 29, 2609-2613 (1991)

[24] 浦沢正三, 谷口孝喜, 小林宣道 : ウイルス, 42, 145153 (1992)

[25] Vilcek S, Herring AJ, Netteton PF, Lowing JP, Peton DJ, : Virus Res, 43, 137-147 (1996)

[26] Wyatt RG, Sly DL, London WT, Palmer AE, Kalica AR, Van Kirk DH, Chanock RM, Kapikian AZ : Arch Virol, 50, 17-27 (1976)

[27］八柳 潤, 齋藤志保子, 森田盛大：感染症学雑誌, 69, 1286-1293 (1995)

\section{The Role of the Group A Rotavirus in Adult-cow Diarrhea \\ Narihisa ONUMA*†, Kazuma KUDO, Shuji OGAWA, Mami SAKURADA, Eiko SUNAHARA, Takahiro MAWATARI, and Hirosi TSUNEMITSU \\ * Chuo Liverstock Hygiene Service Center, 1-15-5 Terauchi-Hirune, Akita, 011-0904, Japan}

\section{SUMMARY}

Bacterial and parasitic pathogens were negative in fecal samples taken from three adult diarrheal cows on a dairy farm in Akita Prefecture in January 2001, Electron microcopy revealed only rotavirus particles in the samples. RNA-polyacrylamide gel electrophoresis detected group-A rotavirus (GAR) RNA segments. GAR was isolated from two samples with MA104 cells, the VP7 serotype of which was G6 and the VP4 genotype of which was $P[1]$. Significant GAR antibody response was observed in two affected and one non-affected cow. Results indicate that GAR infection caused diarrhea in the adult cows in this study.

- Key words : adult cows, diarrhea, group A rotavirus, serotype, virus-neutralizing antibody.

$\dagger$ Correspondence to : Narihisa ONUMA (Chuo Liverstock Hygiene Service Center)

1-15-5 Terauchi-Hirune, Akita, 011-0904, Japan TEL 018-864-0401 FAX 018-862-7132

J. Jpn. Vet. Med. Assoc., 56, $245 \sim 248$ (2003) 